\title{
Signalling Effects Induced by Acid Ceramidase in Human Epithelial Or Leukemic Cell Lines
}

\author{
Käthe Baduva ${ }^{a} \quad$ Lara Büchter $^{\mathrm{a}} \quad$ Katja Kreyenkamp ${ }^{\mathrm{a}} \quad$ Linnea Westphal $^{\mathrm{a}}$ \\ Barbara Wilker $^{b} \quad$ Marcus Kohnen ${ }^{a}$ Edward H. Schuchman ${ }^{c}$ Michael J. Edwards ${ }^{d}$ \\ Katrin Anne Becker ${ }^{b} \quad$ Erich Gulbins $^{\mathrm{b}, \mathrm{d}} \quad$ Alexander Carpinteiro ${ }^{\mathrm{b}}$ \\ aGymnasium Essen-Werden, Essen, Germany, ${ }^{b}$ Department of Molecular Biology, Medical School, \\ University of Duisburg-Essen, Essen, Germany, 'Department of Genetics \& Genomic Sciences, Icahn \\ School of Medicine at Mount Sinai, New York, NY, USA, dDepartment of Surgery, University of \\ Cincinnati, College of Medicine, University of Cincinnati, Cincinnati, OH, USA
}

\section{Key Words}

Acid ceramidase $\cdot$ Signalling $\cdot$ Epithelial cells $•$ Lymphocytes $•$ Cystic fibrosis

\begin{abstract}
Background/Aims: Recent studies indicated that an inhalation treatment of cystic fibrosis mice with acid ceramidase prevents and eliminates infections with Pseudomonas aeruginosa and Stapyhlococcus aureus. Inhalation of acid ceramidase facilitated the elimination of $P$. aeruginosa in acutely- or chronically-infected mice with cystic fibrosis. Thus, inhalation of acid ceramidase might be a preventive and/or curative treatment for patients with cystic fibrosis suffering from pneumonia. Methods: We treated cultured epithelial cells or leukemic T-lymphocytes (Jurkat cells) with purified acid ceramidase and determined intracellular signalling events, proliferation and cell survival. Specifically, we measured the activity of AKT, p38-kinase and p70S6-kinase using activation-specific phospho-antibodies in western blot studies. Trypan Blue staining served to analyze proliferation and cell survival. Results: Our studies indicate that treatment of Chang epithelial cells or Jurkat T lymphocytes with purified acid ceramidase results in a dose dependent activation of AKT, p38-kinase and p70S6-kinase, while tyrosine phosphorylation of intracellular proteins remains largely unchanged. Acid ceramidase treatment did not change expression of tight junction proteins such as ZO-1, ZO-2 and occludin. Cellular viability and proliferation were not affected by acid ceramidase treatment. Conclusion: Our data suggest that treatment of epithelial cells and lymphocytes with acid ceramidase results in activation of distinct pathways, in particular AKT- and p38Kdependent pathways, while no global activation or cell death was observed.
\end{abstract}

E. Gulbins and A. Carpinteiro / K. Baduva, L. Büchter, K. Kreyenkamp, L. Westphal and B. Wilker contributed equally to this work 


\section{Cellular Physiology Cell Physiol Biochem 2019;52:1092-1102 \\ \begin{tabular}{ll|l} 
and Biochemistry $10.33594 / 000000074$ & (c) 2019 The Author(s). Published by \\
Cell Physiol Biochem Press GmbH\&Co. KG
\end{tabular} \\ Baduva et al.: Signalling Induced by Acid Ceramidase}

These findings support the notion that inhalation of acid ceramidase could be developed to a treatment in cystic fibrosis patients, although further in vivo studies are required.

(C) 2019 The Author(s). Published by Cell Physiol Biochem Press GmbH\&Co. KG

\section{Introduction}

Acid ceramidase (N-acylsphingosine aminohydrolase; gene symbol Asah1, for the mouse; ASAH1 for humans) hydrolyzes the amide ester bond in ceramide and thereby converts ceramide to sphingosine with the release of a fatty acid [1]. It is a lysosomal enzyme with a $\mathrm{pH}$ optimum of $\sim 4.5$, and has a primary housekeeping function in the metabolism of cell membranes. The complete absence of AC activity in mice results in early embryonal death, and in man ASAH1 mutations that reduce AC activity leads to the development of two complex and severe syndromes, Farber disease and Spinal Muscular Atropy with Myoclonic Epilepsy (SMA-PME) [1, 2]. Farber disease is characterized by severe joint contractures and the presence of painful joint nodules, and, depending on the severity of the disorder, neurological symptoms, alterations of the liver, spleen and lung, and premature death $[1,2]$. SMA-PME is characterized by progressive muscle weakness associated with the degeneration of spinal cord neurons, followed by the onset of myoclonic seizures. Patients with acid ceramidase deficiency who have a phenotype intermediate between Farber and SMA-PME also have been described $[1,2]$.

We and others have previously shown that ceramide accumulates in airway epithelial cells and macrophages from mice and patients with cystic fibrosis [3-15]. In particular, these studies detected a significant increase of C16, C18 and C20 ceramide species in epithelial cells of the upper airways $[7,14,16]$. The increase of ceramide was detected in a variety of cystic fibrosis cells, including human and mouse lung tissue, human nasal polyps, freshly isolated human nasal epithelial cells, human sputum cells, mouse alveolar macrophages and cultured airway epithelial cells from cystic fibrosis patients, as well as in different genetic models of $C$ ftr-deficient mice [3-15].

Cystic fibrosis is caused by mutations in the cystic fibrosis transmembrane conductance regulator (CFTR) gene $[17,18]$. With an incidence of $\sim 1$ in 2500 births it is the most common autosomal recessive disorder in the EU and the USA [18]. In the EU and the USA combined, approximately 80000 children and young adults are affected with cystic fibrosis. Clinically, the most important symptoms are gastrointestinal symptoms such as malabsorption and malnutrition, and pulmonary inflammation and infections. While the gastrointestinal problems are relatively well-controlled by treatment, the pulmonary problems are still very severe and are characterized by chronic inflammation of the airways as well as recurrent and chronic infections with Pseudomonas aeruginosa, Burkholderia cepacia, Staphylococcus aureus, Haemophilus influenzae and other pathogens, and finally bronchiectasis and fibrosis [19-21].

We have shown that ceramide plays a central role in the pathophysiology of lung alterations in cystic fibrosis $[3,5,11,22]$. Thus, genetic or pharmacological inhibition of acid sphingomyelinase, an enzyme that produces ceramide from sphingomyelin, reduces inflammation and infection susceptibility in mouse models of cystic fibrosis [3, 22].

In addition to increased concentrations of ceramide in cystic fibrosis tracheal and bronchial epithelial cells, sphingosine levels are drastically reduced in airway epithelial cells from cystic fibrosis patients compared to the levels in healthy airways $[11,22$, 23]. Sphingosine, a sphingoid long-chain base, kills a variety of pathogens including P. aeruginosa, Acinetobacter baumannii, Haemophilus influenzae, Burkholderia cepacia, Moraxella catarrhalis, Escherichia coli, Fusobacterium nucleatum, Streptococcus sanguinis, Streptococcus mitis, Corynebacterium bovis, Corynebacterium striatum and Corynebacterium jeikeium [11, 22, 24-27]. We have shown that sphingosine functions as an important firstline defense against $P$. aeruginosa colonization in healthy airways $[11,22,23]$. The lack of sphingosine in cystic fibrosis cells greatly increases susceptibility to bacterial pathogens, 


\section{Cellular Physiology Cell Physiol Biochem 2019;52:1092-1102

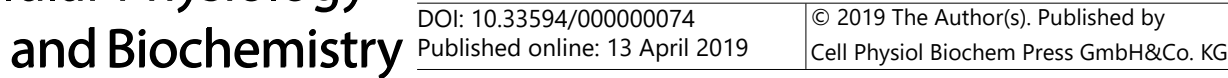 \\ Baduva et al.: Signalling Induced by Acid Ceramidase}

and reconstitution of sphingosine in airways of mice with cystic fibrosis or freshly isolated human airway epithelial cells restores the ability of epithelial cells to kill pathogens and to prevent the development of a pneumonia [11,22].

Based on these findings it was shown that treatment of cystic fibrosis mice with drugs that reduce ceramide formation or inhalation of sphingosine, reduces inflammation and/or pulmonary infections in cystic fibrosis mice [3, 11, 22, 23]. Inhalation of acid ceramidase, the enzyme catalyzing the deacetylation of ceramide to generate sphingosine, was also effective as treatment in cystic fibrosis mice and prevented infections of these mice with $P$. aeruginosa $[11,22]$. However, these experiments only studied short-term application of acid ceramidase, while the treatment of patients with cystic fibrosis would clearly require a longterm treatment with the enzyme. Thus, to exclude the likelihood of severe side effects of a treatment with acid ceramidase, we investigated whether treatment of human epithelial cells or T lymphocytes with the purified enzyme results in a change in the activity of intracellular signaling molecules, cell viability and proliferation.

\section{Materials and Methods}

\section{Cells and stimulation}

Chang cells, a human conjunctiva epithelial cell line, and Jurkat cells, a human T-cell lymphoma line, were cultured in RPMI-1640 supplemented with 10 mM HEPES (pH 7.4, Carl Roth GmbH, Karlsruhe, Germany), $2 \mathrm{mM}$ L-glutamine, $1 \mathrm{mM}$ sodium pyruvate, $100 \mu \mathrm{M}$ nonessential amino acids, $100 \mathrm{U} / \mathrm{mL}$ penicillin, 100 $\mu \mathrm{g} / \mathrm{mL}$ streptomycin (all from Invitrogen) and 10\% fetal calf serum (PAA Laboratories GmbH, Coelbe, Germany). Contamination of Chang cells with Hela cells was excluded. The cell lines were maintained at $37^{\circ} \mathrm{C}$ in a humidified atmosphere at $5 \% \mathrm{CO}_{2}$. Prior to stimulation, Jurkat cells were washed twice in prewarmed HEPES/Saline (H/S; $132 \mathrm{mM} \mathrm{NaCl}, 20 \mathrm{mM}$ HEPES, pH 7.4, $5 \mathrm{mM} \mathrm{KCl}, 1 \mathrm{mM} \mathrm{CaCl}, 0.7 \mathrm{mM} \mathrm{MgCl}_{2}, 0.8 \mathrm{mM}$ $\mathrm{MgSO}_{4}$ ), resuspended in $\mathrm{H} / \mathrm{S}$ and $4 \times 10^{5}$ Jurkat cells in $50 \mu \mathrm{H} / \mathrm{S}$ were aliquoted into Eppendorf tubes. Cells were then equilibrated for $8 \mathrm{~min}$ at $37^{\circ} \mathrm{C}$ with $125 \mathrm{rpm}$ shaking in an Eppendorf thermoshaker and treated with 4 or $20 \mu \mathrm{g} / \mathrm{ml}$ acid ceramidase for $10 \mathrm{~min}$. Control cells were left untreated. In addition, we stimulated leukemic Jurkat T-lymphocytes with $10 \mu \mathrm{g} / \mathrm{mL}$ OKT-3 together with acid ceramidase treatment to investigate whether acid ceramidase alters T-cell receptor/CD3-induced signalling. Treatments were terminated by addition of $55 \mu \mathrm{L}$ lysis buffer consisting of $0.1 \%$ SDS, $25 \mathrm{mM}$ HEPES (pH 7.4), 0.5\% deoxycholate, 0.1\% Triton X-100, $10 \mathrm{mM}$ EDTA, $10 \mathrm{mM}$ sodium pyrophosphate, $10 \mathrm{mM}$ sodium fluoride, $125 \mathrm{mM} \mathrm{NaCl}, 10 \mu \mathrm{g} /$ $\mathrm{ml}$ aprotinin/leupeptin and $10 \mathrm{mM}$ sodium-orthovanadate. The samples were placed on ice and lysis was allowed to complete for $5 \mathrm{~min}$ at $4^{\circ} \mathrm{C}$. Insoluble material was removed by centrifugation at $14000 \mathrm{rpm}$ for 5 min at $4^{\circ} \mathrm{C}$. The supernatants were collected, added to $5 \mathrm{x}$ SDS-Laemmli buffer, boiled for $5 \mathrm{~min}$ and analyzed by western blotting as described below.

Chang cells were cultured in 24-well plates with a density of 50000 cells/well for 24 hrs prior to treatment. The cells were washed twice in $\mathrm{H} / \mathrm{S}, 300 \mu \mathrm{L} \mathrm{H} / \mathrm{S}$ were added to each well and the cells were incubated with 4 or $20 \mu \mathrm{g} / \mathrm{mL}$ acid ceramidase for $10 \mathrm{~min}, 20 \mathrm{~min}, 30 \mathrm{~min}$ and $45 \mathrm{~min}$. Control cells were left untreated. The supernatant was removed and the cells were lysed by addition of $200 \mu \mathrm{L}$ lysis buffer as above. The plates were immediately placed on ice, lysis was allowed to complete for $5 \mathrm{~min}$, the cells were scraped from the plate and the samples were transferred into Eppendorf tubes. The samples were further processed as described above.

\section{Western blots}

Proteins were separated by $8.5 \%$ or $10 \%$ sodium dodecyl sulfate polyacrylamide gel electrophoresis (SDS-PAGE) and electrophoretically transferred onto nitrocellulose membranes. The membranes were washed, blocked with Starting Block Tris-buffered saline (TBS) blocking buffer (ThermoFisherScientific, Darmstadt, Germany) for $45 \mathrm{~min}$, washed twice for 10 min each in TBS supplemented with $0.05 \%$ Tween 20 (TBS/Tw), and incubated for $60 \mathrm{~min}$ at room temperature with anti-phospho-AKT (1:1000, Cell Signalling, \#4056 and \#4058, a 1:1 mixture was used), anti-phospho-p38-kinase (1:1000, Cell Signalling, \#9211), antiphospho-p70S6-kinase (1:1000, Cell Signalling, \#2708), alkaline phosphatase coupled-anti-Actin (1:1000, 


\section{Cellular Physiology Cell Physiol Biochem 2019;52:1092-1102

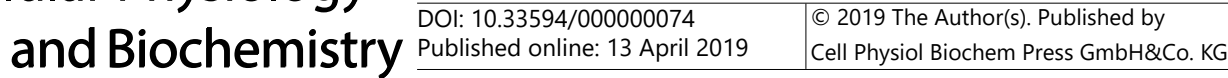 \\ Baduva et al.: Signalling Induced by Acid Ceramidase}

Santa Cruz Inc., \#sc47778), anti-ZO-1 (1:1000, Invitrogen, \#617300), anti-ZO-2 (1:1000, Santa Cruz Inc., \#sc11448), anti-Occludin (1:1000, Invitrogen, \#711500) or anti-phosphotyrosine 4G10 (1:1000, Millipore, \#05-321) antibodies in blocking solution. The blots were washed 6-times, $10 \mathrm{~min}$ each in TBS/Tw and developed with alkaline phosphatase-coupled secondary antibodies (except for the anti-actin body, which was directly coupled) employing the Tropix chemoluminescence system. The blots were quantified using Photoshop.

\section{Cell viability}

Chang and Jurkat cells were cultured as above and stimulated in complete RPMI-1640 with 4 or 20 $\mu \mathrm{g} / \mathrm{mL}$ acid ceramidase for 24, 48 and $72 \mathrm{hrs}$ or left untreated. The doses based on previous experiments, in which we inhaled mice with $25 \mu \mathrm{g} \mathrm{AC}$ in $800 \mu \mathrm{l} 0.9 \% \mathrm{NaCl}$ solution. Since not all of the inhalation fluid reaches the lung, the two doses reflect a very high and an intermediate dose of AC if compared to the inhalation experiments [11]. Cells were then washed in H/S and stained with Trypan Blue. Dead cells were identified by an intense blue staining. We counted at least 500 cells with a hemocytometer and determined the percentage of dead cells. The studies were performed in triplicates.

\section{Cell proliferation}

Chang and Jurkat were cultured as above and stimulated in complete RPMI-1640 with 4 or $20 \mu \mathrm{g} / \mathrm{ml}$ acid ceramidase for 24, 48 and $72 \mathrm{hrs}$ or left untreated. Cells were then washed in H/S and triplicates were counted with a hemocytometer.

\section{Statistics}

Data are expressed as arithmetic means \pm SD. Student's t-test was used to compare two groups. Oneway ANOVA was employed to compare for statistical differences between more than two groups followed by post-hoc Student's t-tests for all pairwise comparisons applying Bonferroni correction for multiple testing. Bonferroni correction was applied prior to calculation of $p$-values for the pairwise comparisons. All values were normally distributed.

\section{Results}

First, we investigated whether incubation of the human cells with acid ceramidase alters cell viability and/or proliferation. These studies were performed to exclude a toxic effect of treatment of cells with acid ceramidase, but also to determine whether a prolonged exposure to acid ceramidase (up to $72 \mathrm{hrs}$ ) induces cell proliferation. The results showed no effect of the acid ceramidase on the viability of Chang epithelial cells or Jurkat lymphocytes, i.e. no increased numbers of dead cells were detected in acid ceramidase-treated samples compared to untreated cells (Fig. 1A and B). Likewise, acid ceramidase treatment did not alter the proliferation of the epithelial cells or lymphocytes (Fig. 1C and D).

While these tests exclude gross cellular changes after treatment with acid ceramidase, they do not allow the determination of subtle alterations of specific signalling pathways. To gain insight into whether acid ceramidase induces changes in specific signalling pathways, we performed western blot studies and measured the phosphorylation of AKT, p38-kinase (p38K) and p70S6-kinase (p70S6K). Phosphorylation of these proteins reflects their activity. Ceramide has been previously shown to regulate AKT [28] and p38K [29] and, therefore, these proteins are good candidates for cellular effects of acid ceramidase.

We also determined tyrosine phosphorylation of cellular proteins in whole cell lysates, since phosphorylation on tyrosine residues initiates and/or is an important component of many signalling pathways.

Since epithelial cells form tight junctions that are important for the concerted function of these cells, we also investigated the expression levels of the tight junction proteins ZO-1, ZO-2 and occludin in Chang epithelial cells prior and after treatment with acid ceramidase.

The results show that treatment with acid ceramidase induced a time and dose dependent phosphorylation/activation of AKT (Fig. 2A, B) in Chang epithelial cells. In 
Fig. 1. Acid ceramidase treatment does not induce cell death or proliferation. Chang $(A, C)$ or Jurkat $(B$, D) cells were treated with acid ceramidase for the indicated times and cell death was determined by trypan blue staining. Cell proliferation was measured by counting the cells. Treatment with the known death stimuli $1 \mu \mathrm{M}$ staurosporine or $10 \mu \mathrm{g} / \mathrm{ml}$ anti-CD95 antibodies $\mathrm{CH} 11$ served as positive control. Given are the mean \pm SD from 4 independent studies, $* * * \mathrm{p}<0.001$, ANOVA.

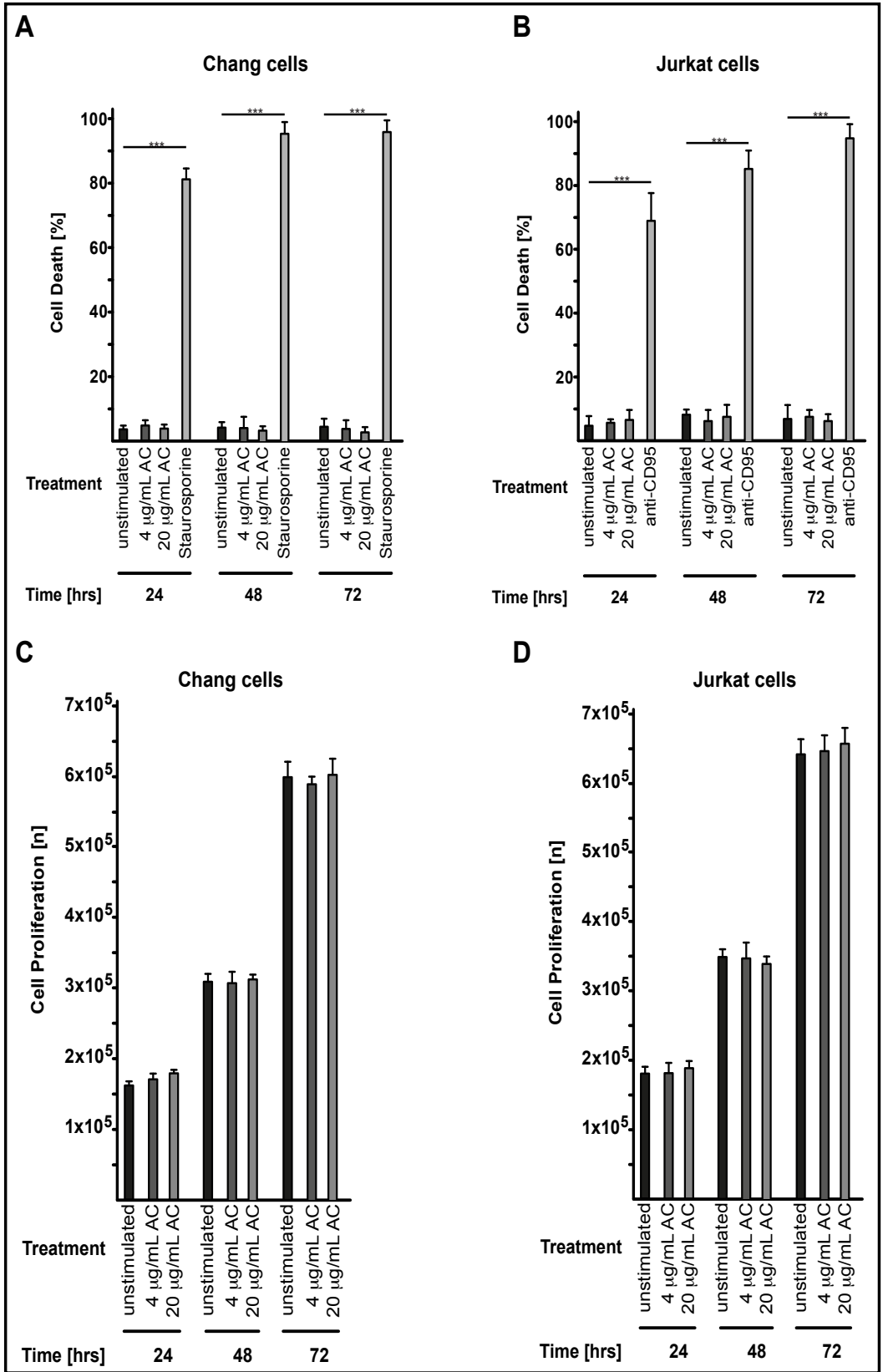

contrast, treatment with acid ceramidase did not alter tyrosine phosphorylation of cellular proteins (Fig. 2A). The expression levels of occludin (Fig. 2A, B), ZO-1 and ZO-2 (Fig. 2C, D) in Chang epithelial cells also were not affected by treatment with acid ceramidase. Tyrosine, Z0-1, ZO-2 and occludin blots show some small variations that were not significant after normalization and analysis of several experiments. In contrast, the stress response kinase p38K was strongly phosphorylated, indicating its stimulation (Fig. 3A, B). p70S6K, a kinase that functions as a global gene expression regulator, was also phosphorylated after treatment of Chang cells with acid ceramidase (Fig. 3C, D).

Similar changes were obtained for Jurkat cells. Acid ceramidase treatment induced an activation of AKT (Fig. 4A, B), while cellular tyrosine phosphorylation remained relatively unchanged with a small increase of phosphorylation of proteins with an apparent molecular weight of 56, 58 and $70 \mathrm{kDa}$ (Fig. 4C) when compared to activation of Jurkat cells with OKT-3. 
Fig. 2. Treatment with acid ceramidase induces AKT activation in Chang cells, but does not induce tyrosine phosphorylation or changes in tight junction proteins. (A, B) Chang cells were treated with acid ceramidase as indicated and the phosphorylation of AKT as well as tyrosine phosphorylation of cellular proteins was analyzed by western blotting. (A-D) Treatment with acid ceramidase does not alter expression levels of the tight junction proteins occludin, ZO-1 and ZO-2. Shown are representative blots (A, C) from 3 independent studies and the q u a n t it a t iv e analysis (B, D) of

A
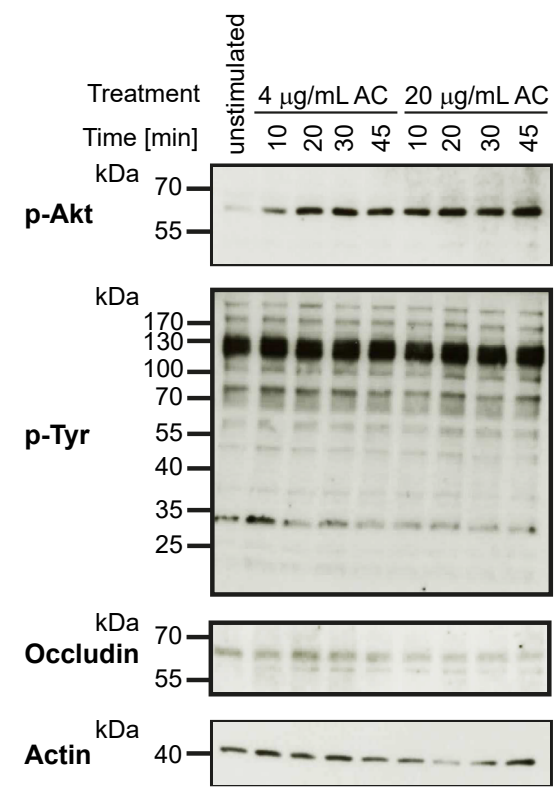

C

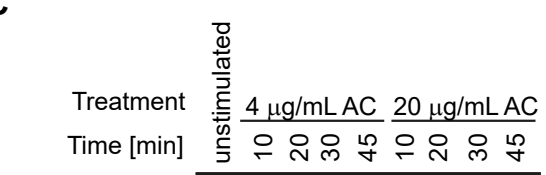

ZO-1
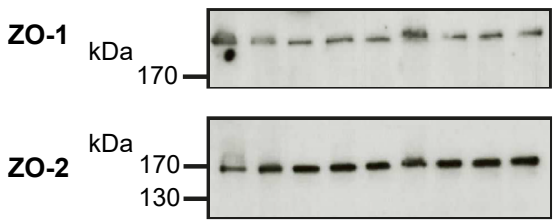

Actin

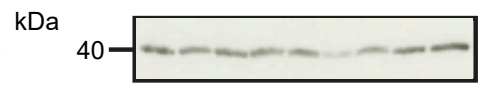

B
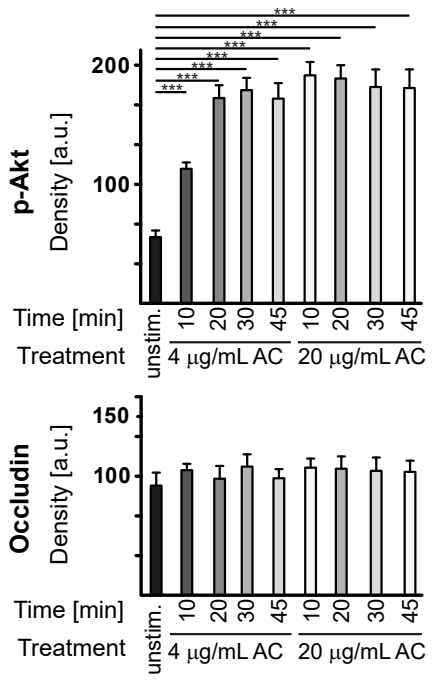

D
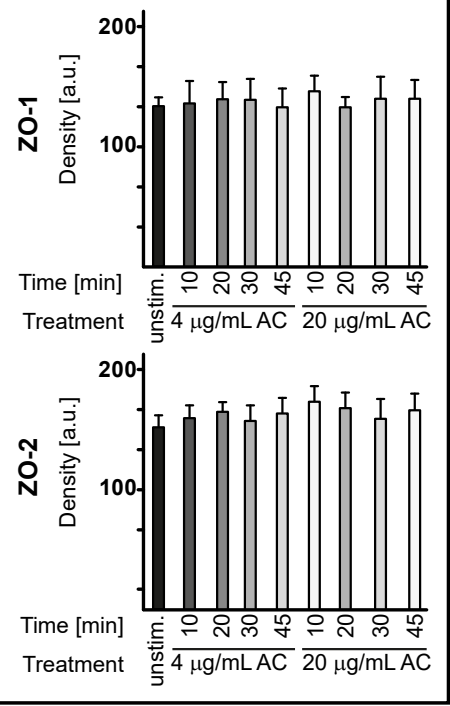

the blots. Actin blots

were used to normalize the samples and to show similar loading in all lanes. The quantitative data are normalized to actin. The quantitative data are mean $\pm S D, n=3,{ }^{*} p<0.05$, ANOVA.

We also analyzed whether treatment of Jurkat lymphocytes with acid ceramidase alters signalling events induced by stimulation via the T cell receptor/CD3 (TCR/CD3) complex. To this end, the T-cells were stimulated with OKT3-antibodies and acid ceramidase, and cellular tyrosine and AKT phosphorylation were determined. The results revealed that acid ceramidase treatment did not alter TCR/CD3-induced signalling (Fig. 4A-C).

\section{Discussion}

Ceramide levels are increased and sphingosine concentrations are decreased in airway epithelial cells from patients and mice with cystic fibrosis [3-16, 22]. Experiments in mice indicated that inhalation of acid ceramidase prevents infection with $P$. aeruginosa and $S$. aureus [11, 22]. Mechanistic studies revealed that an initial accumulation of ceramide in cystic fibrosis cells results in the formation of ceramide-enriched domains in the luminal plasma membrane of airway epithelial cells [22]. These domains trap and cluster $\beta 1$-integrin molecules in the luminal plasma membrane of cystic fibrosis cells, while $\beta 1$-integrin is absent 


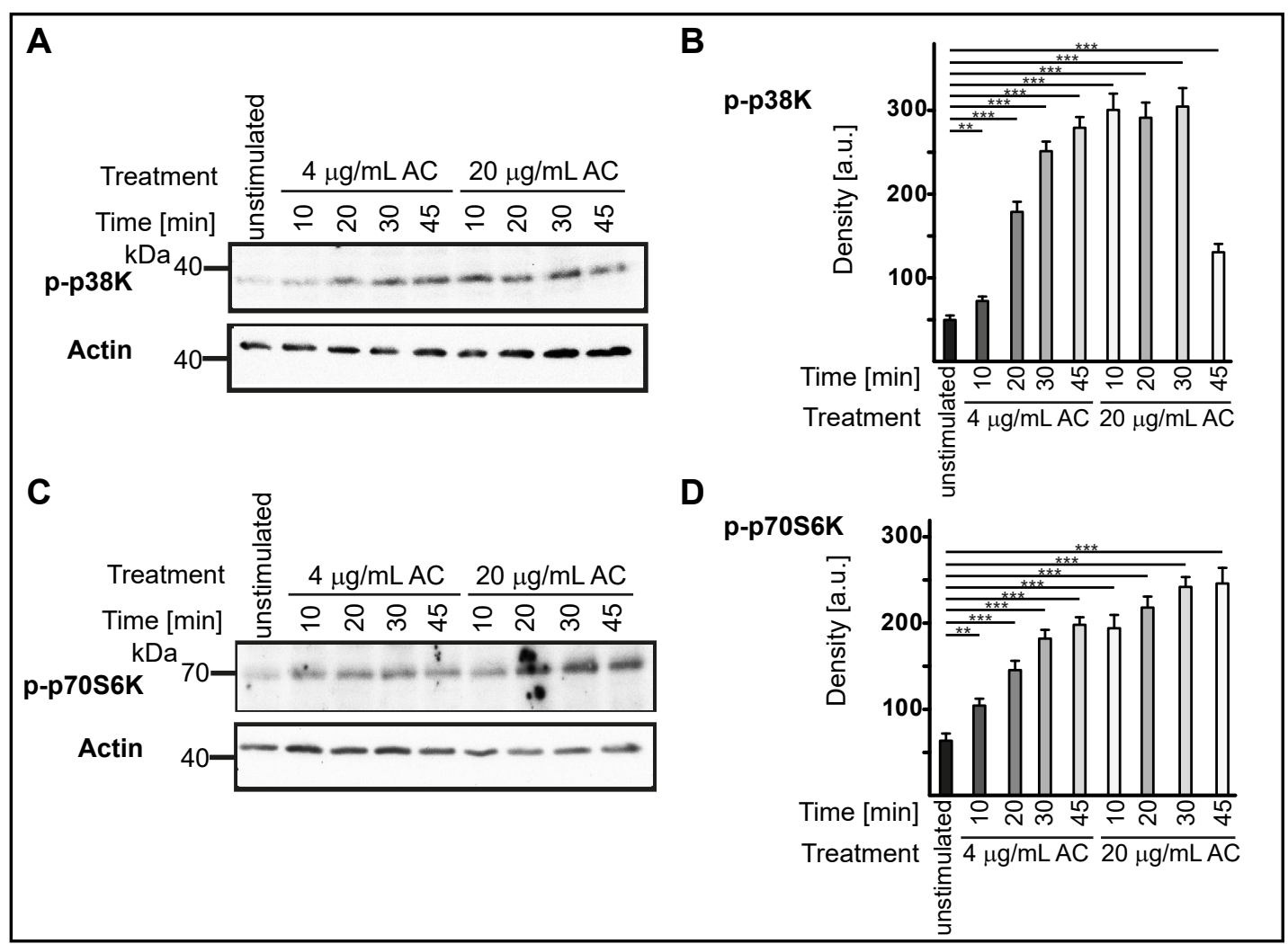

Fig. 3. Acid ceramidase treatment of Chang cells activates p38-kinase and p70S6-kinase. Chang cells were treated with acid ceramidase as indicated and the phosphorylation of p38-kinase (p-p38K) (A, B) and p70S6K (C, D) was analyzed by western blotting (A, C) and quantified (B, D). Treatment with acid ceramidase results in activation of both proteins. Shown are representative blots (A, C) from 3 independent studies and the quantitative analysis (B, D) of the blots. Actin blots were used to normalize the samples and to show similar loading in all lanes. The quantitative data are normalized to actin. The quantitative data are mean \pm SD, $n=4$ for phospho-p38K and $n=5$ for phospho-p70S6K, ${ }^{*} \mathrm{p}<0.05$, ANOVA.

from the luminal membrane of healthy airway epithelial cells [22]. The ectopic expression of $\beta 1$-integrin in the luminal membrane results in a down-regulation of acid ceramidase in cystic fibrosis cells. The molecular mechanisms of this down-regulation remain to be determined. The reduced expression of acid ceramidase in cystic fibrosis cells results in further accumulation of ceramide and a down-regulation of sphingosine, a vicious cycle that results in inflammation and increased infection susceptibility to bacterial lung infections [22]. Inhalation of acid ceramidase disrupts this cycle and restores the resistance to bacterial infections in cystic fibrosis mice.

Thus, inhalation of acid ceramidase might be a potential, novel treatment of the patients with cystic fibrosis. However, it is unknown whether acid ceramidase has adverse effects on epithelial cells and immune cells present in the lung. Here, we demonstrate that treatment of epithelial or lymphocyte cell lines with acid ceramidase does not affect viability and does not induce any cell proliferation, suggesting that inhalation of acid ceramidase should be relatively safe and not cause gross damage to the cells. This notion is consistent with the finding that acid ceramidase treatment did not alter the expression levels of ZO-1, ZO-2 and occludin in Chang epithelial cells.

However, western blot studies revealed that treatment of epithelial cells or lymphocytes with acid ceramidase resulted in a partial activation of the cells, in particular an activation of AKT. The activation of these signalling events might indicate a stress response of the cells. Indeed, a reduction of cellular ceramide levels has been previously shown to induce activation of AKT and has been linked to cell survival, proliferation and differentiation [28]. 


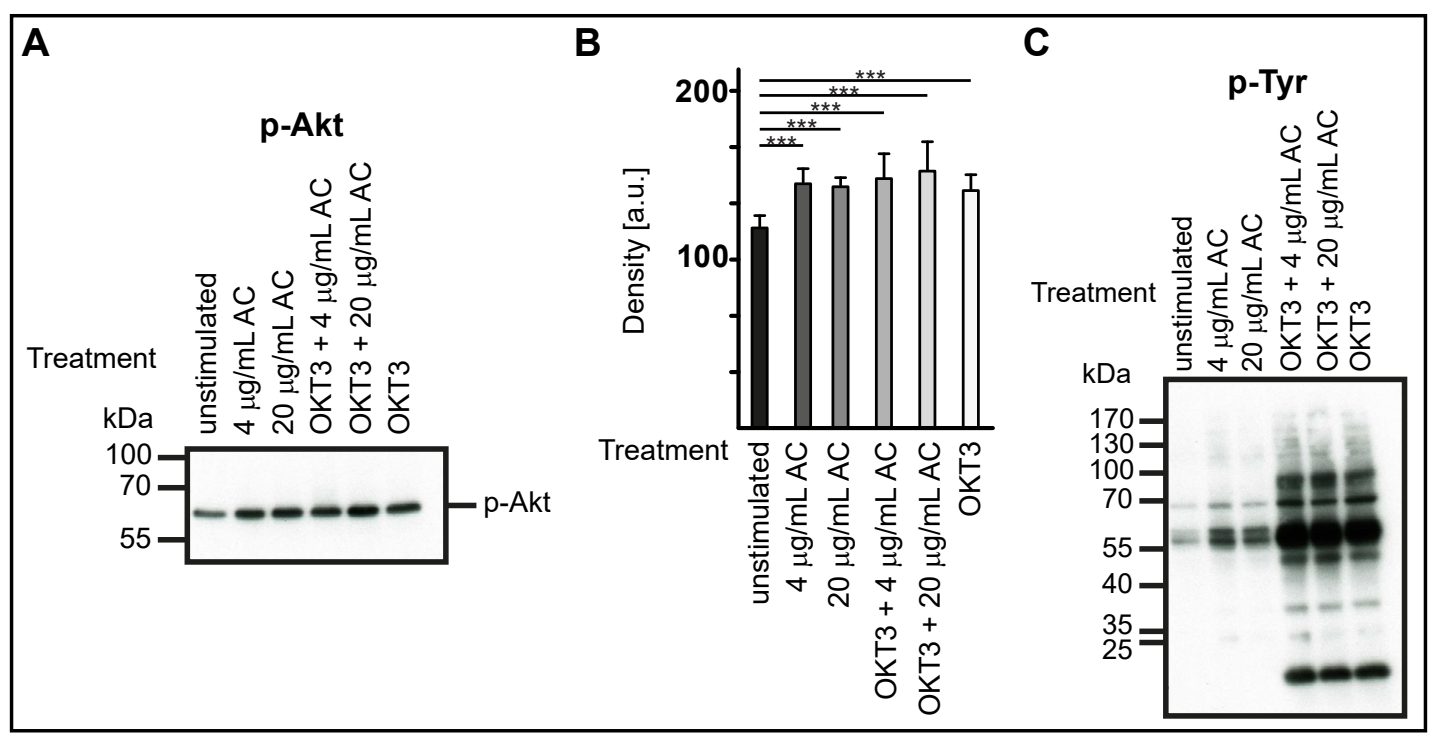

Fig. 4. Treatment with acid ceramidase induces AKT activation and some tyrosine phosphorylation in Jurkat cells, but does not alter TCR/CD3-induced cell activation. Jurkat T lymphocytes were treated with acid ceramidase as indicated and the phosphorylation of AKT (A, B) or cellular tyrosine phosphorylation (C) was measured by western blotting. In addition, Jurkat cells were stimulated via the TCR/CD3 complex using $10 \mu \mathrm{g} / \mathrm{ml} \mathrm{OKT-3}$ antibodies in the presence or absence or acid ceramidase. The results show that acid ceramidase induces a phosphorylation/ activation of AKT and a tyrosine phosphorylation of some proteins with an apparent weight of 56, 58 and $70 \mathrm{kDa}$, but does not alter TCR/CD3-mediated T cell activation.Cells were counted prior to any assay and equal numbers were used in each sample. Shown are representative blots from 3 independent experiments $(A, C)$ and the quantitative analysis (B). Given are the mean $\pm S D, n=3$, ${ }^{*} \mathrm{p}<0.05$, ANOVA.

The western blot studies in lymphocytes also indicate a mild activation of proteins with apparent molecular weight of 56, 58 and $70 \mathrm{kDa}$. These proteins might be Src-like tyrosine kinases such as Lck and Fyn, as well as Zap70, indicating that acid ceramidase might induce an abortive activation of T lymphocytes, which could result in an apoptosis of these cells. This was not observed in the studies measuring apoptosis, but should be closely monitored in an in vivo study.

Previous reports demonstrated that increased expression of the acid ceramidase promotes cell growth, in particular tumor cell growth [30]. Here, we demonstrated that exogenous application of the acid ceramidase to epithelial cells and Jurkat T lymphocytes had no effect on the growth/proliferation of these cells. This difference might be explained by the fact that many tumor cells also show an upregulation of sphingosine-kinases resulting in increased turnover of sphingosine and higher levels of sphingosine-1-phosphate that, together with decreased levels of ceramide may trigger proliferation of tumor cells. Exogenous application of acid ceramidase does not increase expression of sphingosinekinases and, thus, might be insufficient to trigger proliferation.

Previous studies have shown that the acid sphingomyelinase is not required for activation via the TCR/CD3 complex [31]. The formation of the immunological synapse seems to involve the neutral sphingomyelinase, but not the acid sphingomyelinase [31]. Since the neutral sphingomyelinase generates ceramide oriented to the cytoplasm, exogenous treatment with acid ceramidase will not affect this pool of ceramide. However, the acid sphingomyelinase seems to important for signaling via co-receptors, in particular IL-2 and CD28 [32, 33]. Thus, under conditions that involve or require these co-receptors, the acid ceramidase might also (indirectly) determine signalling via the TCR/CD3 complex by down-regulation of ceramide generated by the acid sphingomyelinase. 


\section{Cellular Physiology Cell Physiol Biochem 2019;52:1092-1102

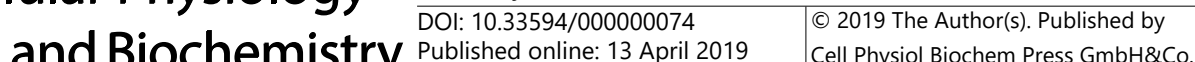 \\ Baduva et al.: Signalling Induced by Acid Ceramidase}

\section{Conclusion}

In summary, our studies indicate that treatment of Chang epithelial cells and Jurkat $T$ lymphocytes with pharmacological doses of acid ceramidase is relatively safe and does not induce toxic effects. However, we did observe a distinct activation of AKT, p38K and p70S6K in the treated cells. These proteins are linked to a variety of essential cellular signalling pathways, and suggest that the effects of acid ceramidase on cystic fibrosis cells and animals should be characterized further prior to clinical application. To further study beneficial vs toxic effects of a treatment of cystic fibrosis cells with acid ceramidase, it will be necessary to treat cultured human respiratory epithelial cells from healthy controls and CF patients with acid ceramidase, inhale wildtype and CF mice for different time intervals with different doses of acid ceramidase, transfer the inhalation protocols to larger animals such as pigs and then perform phase I clinical studies.

\section{Acknowledgements}

The study was supported by DFG grants GRK 2098 to EG and KBF. KB, LB, KK, LW, BW, $\mathrm{AC}$ and EG performed the experiments. EG, EHS and AC wrote the manuscript and analyzed the data. EHS provided purified acid ceramidase. MK, ES, MJE, KAB, EG and AC planned the project. All authors have read the manuscript and agreed to it.

\section{Disclosure Statement}

The authors declare to have no conflicts of interest.

\section{References}

1 Frohbergh M, He X, Schuchman EH: The molecular medicine of acid ceramidase. Biol Chem 2015;396:759765.

2 Park JH, Schuchman EH: Acid ceramidase and human disease. Biochim Biophys Acta 2006;1758:21332138.

- 3 Teichgräber V, Ulrich M, Endlich N, Riethmüller J, Wilker B, De Oliveira-Mundin CC, van Heeckeren AM, Barr ML, von Kürthy G, Schmid KW, Weller M, Tümmler B, Lang F, Grassmé H, Döring G, Gulbins E: Ceramide accumulation mediates inflammation, cell death and infection susceptibility in cystic fibrosis. Nat Med 2008;14:382-391.

- 4 Zhang Y, Li X, Grassmé H, Döring G, Gulbins E: Alterations in ceramide concentration and pH determine the release of reactive oxygen species by Cftr-deficient macrophages on infection. J Immunol 2009;184:51045111.

5 Becker KA, Riethmüller J, Lüth A, Döring G, Kleuser B, Gulbins E: Acid sphingomyelinase inhibitors normalize pulmonary ceramide and inflammation in cystic fibrosis. Am J Respir Cell Mol Biol 2010;42:716724.

6 Ulrich M, Worlitzsch D, Viglio S, Siegmann N, Iadarola P, Shute JK, Geiser M, Pier GB, Friedel G, Barr ML, Schuster A, Meyer KC, Ratjen F, Bjarnsholt T, Gulbins E, Döring G: Alveolar inflammation in cystic fibrosis. J Cyst Fibros 2010;9:217-227.

7 Brodlie M, McKean MC, Johnson GE, Gray J, Fisher AJ, Corris PA, Lordan JL, Ward C: Ceramide is increased in the lower airway epithelium of people with advanced cystic fibrosis lung disease. Am J Respir Crit Care Med. 2010;182:369-375.

8 Bodas M, Min T, Mazur S, Vij N: Critical modifier role of membrane-cystic fibrosis transmembrane conductance regulator-dependent ceramide signaling in lung injury and emphysema. J Immunol 2011;186:602-613. 


\section{Cellular Physiology Cell Physiol Biochem 2019;52:1092-1102 \begin{tabular}{l|l|l} 
and Biol: 10.33594/000000074 & (c)19 The Author(s). Published by
\end{tabular} and BIOChemistry Published online: 13 April $2019 \quad$ Cell Physiol Biochem Press GmbH\&Co. KG \\ Baduva et al.: Signalling Induced by Acid Ceramidase}

- 9 Caretti A, Bragonzi A, Facchini M, De Fino I, Riva C, Gasco P, Musicanti C, Casas J, Fabriàs G, Ghidoni R, Signorelli P: Anti-inflammatory action of lipid nanocarrier-delivered myriocin: therapeutic potential in cystic fibrosis. Biochim Biophys Acta 2014;1840:586-594.

10 Itokazu Y, Pagano RE, Schroeder AS, O'Grady SM, Limper AH, Marks DL: Reduced GM1 ganglioside in CFTRdeficient human airway cells results in decreased $\beta 1$-integrin signaling and delayed wound repair. Am J Physiol Cell Physiol 2014;306:C819-830.

11 Pewzner-Jung Y, Tavakoli Tabazavareh S, Grassmé H, Becker KA, Japtok L, Steinmann J, Joseph T, Lang S, Tuemmler B, Schuchman EH, Lentsch AB, Kleuser B, Edwards MJ, Futerman AH, Gulbins E: Sphingoid long chain bases prevent lung infection by Pseudomonas aeruginosa. EMBO Mol Med 2014;6:1205-1214.

12 Becker KA, Henry B, Ziobro R, Tümmler B, Gulbins E, Grassmé H: Role of CD95 in pulmonary inflammation and infection in cystic fibrosis. J Mol Med (Berl.) 2012;90:1011-1023.

13 Quinn RA, Lim YW, Mak TD, Whiteson K, Furlan M, Conrad D, Rohwer F, and Dorrestein P: Metabolomics of pulmonary exacerbations reveals the personalized nature of cystic fibrosis disease. Peer J 2016;4:e2174.

14 Caretti A, Vasso M, Bonezzi FT, Gallina A, Trinchera M, Rossi A, Adami R, Casas J, Falleni M, Tosi D, Bragonzi A, Ghidoni R, Gelfi C, Signorelli P: Myriocin treatment of CF lung infection and inflammation: complex analyses for enigmatic lipids. Naunyn Schmiedebergs Arch Pharmacol 2017;390:775-790.

- 15 Schiumarini D, Loberto N, Mancini G, Bassi R, Giussani P, Chiricozzi E, Samarani M, Munari S, Tamanini A, Cabrini G, Lippi G, Dechecchi MC, Sonnino S, Aureli M. Evidence for the involvement of lipid rafts and plasma membrane sphingolipid hydrolases in Pseudomonas aeruginosa infection of cystic fibrosis bronchial epithelial cells. Mediators Inflamm 2017;2017:1730245.

16 Garić D, De Sanctis JB, Wojewodka G, Houle D, Cupri S, Abu-Arish A, Hanrahan JW, Hajduch M, Matouk E, Radzioch D. Fenretinide differentially modulates the levels of long- and very long-chain ceramides by downregulating Cers5 enzyme: evidence from bench to bedside. J Mol Med (Berl) 2017;95:1053-1064.

17 Ratjen F, Döring G: Cystic fibrosis. Lancet 2003;361:681-689.

- 18 Elborn JS: Cystic fibrosis. Lancet 2016;388:2519-2531.

- 19 Van Biervliet S, de Clercq C, Declercq D, Van Braeckel E, Van Daele S, De Baets F, De Looze D: Gastrointestinal manifestations in cystic fibrosis patients. Acta Gastroenterol Belg 2016;79:481-486.

20 Hurley MN, McKeever TM, Prayle AP, Fogarty AW, Smyth AR: Rate of improvement of CF life expectancy exceeds that of general population-observational death registration study. J Cyst Fibros 2014;13:410-415.

21 CF foundation, patient registry annual report. (Bethesda, Maryland, U.S.A, 2010). http://www.cff.org/ livingwithcf/carecenternetwork/patientregistry/.

22 Grassmé H, Henry B, Ziobro R, Becker KA; Riethmüller J, Gardner A, Seitz AP, Steinmann J, Lang S, Ward C, Schuchman EH, Caldwell CC, Kamler M, Edwards MJ, Brodlie M, Gulbins E: $\beta 1$-integrin accumulates in cystic fibrosis luminal airway epithelial membranes and decreases sphingosine promoting bacterial infections. Cell Host and Microbes 2017;21:707-718.

23 Tavakoli Tabazavareh S, Seitz A, Jernigan P, Sehl C, Keitsch S, Lang S, Kahl BC, Edwards M, Grassmé H, Gulbins E, Becker KA: Lack of sphingosine causes susceptibility to pulmonary Staphylococcus aureus infections in cystic fibrosis. Cell Physiol Biochem 2016;38:2094-2102.

24 Bibel DJ, Aly R, Shinefield HR: Antimicrobial activity of sphingosines. J Invest Dermatol 1992;98:269-273.

- 25 Arikawa J, Ishibashi M, Kawashima M, Takagi Y, Ichikawa Y, Imokawa G: Decreased levels of sphingosine, a natural antimicrobial agent, may be associated with vulnerability of the stratum corneum from patients with Atopic Dermatitis to colonization by Staphylococcus aureus. J Invest Dermatol 2002;119:433-439.

26 Fischer CL, Walters KS, Drake DR, Blanchette DR, Dawson DV, Brogden KA, Wertz PW: Sphingoid bases are taken up by Escherichia coli and Staphylococcus aureus and induce ultrastructural damage. Skin Pharmacol Physiol 2013;26:36-44.

27 LaBauve AE, Wargo MJ: Detection of host-derived sphingosine by Pseudomonas aeruginosa is important for survival in the murine lung. PLoS Pathog 2014;10:e1003889.

28 Gulbins E, Palmada M, Reichel M, Lüth A, Böhmer C, Amato D, Müller CP, Tischbirek CH, Groemer TW, Tabatabai G, Becker KA, Tripal P, Staedtler S, Ackermann TF, v. Brederode J, Alzheimer C, Weller M, Lang UE, Kleuser B, Grassmé H, Kornhuber J: Acid sphingomyelinase/ceramide system mediates effects of antidepressant drugs. Nat Med 2013;19:934-938.

29 Grassmé H, Jernigan PL, Hoehn RS, Wilker B, Soddemann M, Edwards MJ, Müller CP, Kornhuber J, Gulbins E: Inhibition of acid sphingomyelinase by antidepressants counteracts stress-induced activation of p38kinase in major depression. Neurosignals 2015;23:84-92. 


\section{Cellular Physiology Cell Physiol Biochem 2019;52:1092-1102}

\begin{tabular}{ll|l} 
and Biochemistry $10.33594 / 000000074$ & $\begin{array}{l}\text { O } 2019 \text { The Author(s). Published by } \\
\text { Cell Physiol Biochem Press GmbH\&Co. KG }\end{array}$ \\
\cline { 2 - 3 }
\end{tabular}

Baduva et al.: Signalling Induced by Acid Ceramidase

30 Saad AF, Meacham WD, Bai A, Anelli V, Elojeimy S, Mahdy AE, Turner LS, Cheng J, Bielawska A, Bielawski J, Keane TE, Obeid LM, Hannun YA, Norris JS, Liu X: The functional effects of acid ceramidase overexpression in prostate cancer progression and resistance to chemotherapy. Cancer Biol Ther 2007;6:1455-1460.

- 31 Börtlein C, Draeger A, Schoenauer R, Kuhlemann A, Sauer M, Schneider-Schaulies S, Avota E: The neutral sphingomyelinase 2 is required to polarize and sustain T Cell receptor signaling. Front Immunol 2018;9:815.

32 Stoffel B, Bauer P, Nix M, Deres K, Stoffel W: Ceramide-independent CD28 and TCR signaling but reduced IL-2 secretion in T cells of acid sphingomyelinase-deficient mice. Eur J Immunol 1998;28:874-880.

- 33 Boucher LM, Wiegmann K, Fütterer A, Pfeffer K, Machleidt T, Schütze S, Mak TW, Krönke M: CD28 signals through acidic sphingomyelinase. J Exp Med 1995;181:2059-2068. 